\title{
MILITANCY AND PRAGMATISM
}

\author{
AN INTERNATIONAL PERSPECTIVE ON MARITIME LABOUR, \\ 1870-1914*
}

SUMMARY: The militancy of maritime workers led worldwide to strikes of great magnitude, visibility and impact. In many countries these strikes had vast repercussions for the industrial and political development of the labour movement. As this comparative overview of maritime labour and unionism in some ten countries shows, however, after the first wave of strikes two conflicting tendencies arose which became a permanent feature of the maritime scene. The men themselves never lost their potential for militant action and adherence to radical ideologies. By contrast, many union leaders became increasingly pragmatic and even accommodationist. This article investigates the causes of this dichotomy and assesses the resulting tensions and conflicts. In many ports these led to break-away moves, spontaneous action and the replacement of moderate by radical leaders. In others the pragmatic tendency survived in power. This included a strong interest in alliances with adjacent unions and international unions.

\section{Introduction}

The historiography of trade unionism and the labour movement in general in recent years has grown at such a frenetic pace that it is doubtful whether any individual can still command or even oversee the whole field. Amongst the plethora of themes several vie for primacy on centre stage: the identity of the proletariat, and the extent and nature of its working-class consciousness and class-war strategies; the identification of chronologically distinct phases in the development of trade unionism and, in particular, the nature of the so-called "new unionism"; the influence of socialist ideology on the developing trade-union movement and, more generally, the relationship between the syndicalist and political wings of the labour movement; and, of more recent vintage, the nature of union leadership and reconstructions and social analyses of workers' lives both on the job and within the circles of their families and communities. The literature, moreover, is increasingly rich in case studies of individual occupation groups, their institutionalized unionism, and, to a lesser extent, their leaders. All these approaches are reflected in the broad perspectives and comparative analyses of the best

\footnotetext{
* I should like to express my deep gratitude to the Alexander von Humboldt-Stiftung of Bonn, without whose generosity in supporting my research in Hamburg this paper could not possibly have been written.
} 
recent syntheses. Somewhat surprisingly, however, there is an almost total lack of studies which deal systematically with the position and influence of individual occupational groups on the overall development of the labour movement at all levels and in all its diverse manifestations or which, in other words, attempt to relate the working and living experiences of the specific group to the external representation of its interests through its ideology, unions, leaders and broader political activity.

Thus, for example, while there is a large number of studies dealing with the industrial sociology of coal miners and the development of both their militancy and their particular local and national trade unions, there was until very recently ${ }^{2}$ no analysis of the influence of coal miners and their leaders in general on the development of national labour movements or, for that matter, the evolution of labour ideology, party organization and political behaviour. In other words, few connections have been made between the experiences of the occupational group at the level of the working and living conditions of its members and its broader ideological, unionist and political significance. In consequence, usually, only a very rough categorisation of workers (skilled, unskilled, or also "semi-skilled") is used and, in consequence, individual occupational groups appear as examples of such categories, not as individually distinct and integral elements of the labour movement. Second, only very few internationally comparative analyses of any such occupational group have been made $;^{2}$ labour history, indeed, still suffers very much from the nationalist approach which, in principle, must be regarded as its very antithesis. But it is just because the working and living conditions of specific occupational groups in different countries could be so similar that it is both inviting and indispensable to adopt an international and comparative perspective in order to assess the structural role of the group within the overall historical pattern of developments. There are many theoretical and historical-empirical problems involved in such an approach, such as the concurrent existence of sharply differing political cultures in countries which, geographically, economically and socially, were not all that far apart. Thus, for example, significant contrasts existed in the timing and manner of the entry of socialists into the

${ }^{2}$ Gary Marks, Unions in Politics. Britain, Germany, and the United States in the Nineteenth and Early Twentieth Centuries (Princeton, 1989), ch. 5.

' See, e.g. James Holt, "Trade Unionism in the British and U.S. Steel Industries, 1880-1914", Labor History, 18 (1977), pp. 5-35; Jeffrey Haydu, "Employers, Unions and American Exceptionalism: Pre-World War I Open Shops in the Machine Trades in Comparative Perspective", International Review of Social History, XXXIII (1988), pp. 25-41; Marks, Unions in Politics; Andrew J. Taylor, Trade Unions and Politics. A Comparative Introduction (London, 1989); and, more directly related to the theme of this essay, Marina Cattaruzza, “ 'Organisierter Konflikt' und 'Direkte Aktion'. Zwei Formen des Arbeiterkampfes am Beispiel der Werftarbeiterstreiks in Hamburg und Triest (1880-1914)", Archiv für Sozialgeschichte, 20 (1980), pp. 325-355. 
national parliamentary political arenas of Great Britain, France, imperial Germany or also Australia and New Zealand and in the relationship between the unionist and political wings of the labour movement of those countries. Similarly, there were significant contrasts in the political culture of the several national labour movements and concepts such as radicalism and syndicalism might, ideologically and in practice, historically as well as historiographically, mean very different things in different countries and at different times. ${ }^{3}$ A research agenda, which calls for the adoption of a broad and international industrial-sociological model based on the comparative study of one particular group of workers, cannot but be fraught with theoretical and practical problems, but I believe that such a methodology could provide valuable new insights into the specific processes of worker militancy and union activity and, more generally, into the ideological and political dialectics and struggles of the working class as a whole.

The purpose of this article is to present such an international comparative analysis of the activity and impact of the particular group of workers which may be defined as maritime labour. As this concept may appear excessively broad, a brief definition and justification of its use may be given first. Maritime labour embraces, above all, the port workers involved in loading and unloading ships and the seamen who sail on them; besides them I also include the numerous semi-skilled and unskilled labourers employed in shipbuilding, repair and maintenance without whose jobs shipping could not be kept moving. The use of this aggregating term should, however, not be understood to mean that we are dealing with a homogeneous labour force which at all times acted as one body; both between and within the three major sections of workers conditions and experiences could vary significantly. Shipyard workers, even leaving highly-skilled engineers and boilermakers out of consideration, included many groups of specialised workers, such as plate makers and rivetters, as well as unskilled general labourers. Similarly, as Hobsbawm and many others after him have emphasised, within the broad range of port transport workers (at least in the major general ports of the pre-Great War world economy) many specific job categories and specialisations existed. ${ }^{4}$ This can be observed both concur-

${ }^{3}$ Cf. Marcel van der Linden, "The National Integration of European Working Classes (1871-1914). Exploring the Causal Configuration", International Review of Social Histo$r y$, XXXIII (1988), pp. 285-311.

"See, e.g., E. J. Hobsbawm, "National Unions on the Waterfront", in Labouring Men (London, 1964), pp. 204-230; John Lovell, Stevedores and Dockers. A Study of Trade Unionism in the Port of London, 1870-1914 (London, 1969); R. Bean, "Employers' Associations in the Port of Liverpool 1890-1914", International Review of Social History, XXI (1976), pp. 358-382; M. J. Daunton, "Inter-Union Relations on the Waterfront: Cardiff 1888-1914", International Review of Social History, XXII (1977), pp. 350-378; Michael Grüttner, Arbeitswelt an der Wasserkante, Sozialgeschichte der Hamburger Hafenarbeiter (Göttingen, 1984); Gordon Phillips and Noel Whiteside, Casual Labour. 
rently and over time, especially with the transition from sail to steam and the consequent introduction of new work situations and employer-employee relations. In fact, until the early stages of the period under discussion, remnants of guilds or guild-like organisations of dock workers and stevedores survived in many ports of Europe while some of the new workers' associations created in the 1870 s resembled more such previous craft bodies than modern trade unions. ${ }^{5}$ Sharp contrasts could also exist in employment conditions and industrial outlook of stevedores (who stowed cargoes in the ships' holds) and dock workers, of the regulars employed by the large liner companies and the far more numerous casuals who constituted the bulk of each port's workforce, of specialised coal trimmers and timber carriers, or also of the otherwise experienced men employed by master stevedores. Important contrasts existed between working conditions for waterside workers dealing with sailing ships and tramps and those employed by regular steamship companies. Similarly, amongst seafarers conditions of employment on sailingships and steamships of liner companies differed markedly while, on the latter, further significant differences existed between deck personnel, stewards and waiters, and firemen and trimmers. ${ }^{6}$ Ship's officers and engineers, it needs hardly to be remarked, formed quite different social and occupational strata which made them, virtually without exception, ${ }^{7}$ stand apart from the remaining crew on board.

Despite the apparent fragmentation of maritime labour there are, I believe, several grounds to propose that this group is both coherent enough

The Unemployment Question in the Port Transport Industry 1880-1970 (Oxford, 1985); and, most recently, John Lovell, 'Sail, Steam and Emergent Dockers' Unionism in Britain, 1850-1914", International Review of Social History, XXXII (1987), pp. 230249.

${ }^{5}$ See, e.g., William H. Sewell, Jr., Structure and Mobility. The Men and Women of Marseille, 1820-1870 (Cambridge, 1985), p. 50, and "Uneven Development, the Autonomy of Politics, and the Dockworkers of Nineteenth-Century Marseille", American Historical Review, 93 (1988), pp. 604-637; Gareth Stedman Jones, Outcast London (Oxford, 1971), ch. 19, and Lovell, "Sail, Steam and Emergent Dockers' Unionism", pp. 233-235.

6 See, e.g., B. Mogridge, "Militancy and Inter-Union Rivalries in British Shipping 1911-1929", International Review of Social History, III (1961), pp. 375-412; Eric Taplin, Liverpool Dockers and Seamen 1870-1890 (Hull, 1974); Alexander Kitroeff, "The Greek Seamen's Movement, 1940-1944", Journal of the Hellenic Diaspora, 7 (1980), pp. 78-79; and Ursula Winkens, "Soziale Lage, rechtliche Rahmenbedingungen und Interessenartikulation der Seeleute im Deutschen Kaiserreich 1872-1914. Ein Beitrag zu einer seemännischen Sozialgeschichte" (Diss., Hamburg, 1987).

${ }^{7}$ The exception is the extraordinary Federazione Italiana dei Lavoratori del Mare established between 1909 and 1911 under the leadership of Captain Giuseppe Giulietti who combined ultra-patriotism with a proto-fascist social ideology which successfully transcended the class differences aboard ship. See Richard E. Webster, L'imperialismo industriale italiano. Studio sul prefascismo 1908-1915 (Turin, 1974), pp. 336-337, and also later in this essay. 
and particularly suitable for a comparative analysis of the kind suggested. First, despite the manyfold fissures that existed in the socio-industrial fabric of maritime workers, as a whole maritime labour had a clearly distinct socio-industrial and subcultural identity ${ }^{8}$ Although a certain proportion of dock labour was skilled and permanently employed, overall its industrial ecology was overwhelmingly characterised by the casual nature of its employment. Similarly, seamen were, to a large extent, engaged from voyage to voyage and, despite the growth of the big liner companies, most did not develop a particular or positive relationship with any particular employer. To a certain level the same may be said about shipyard workers, especially those engaged in repair and maintenance work in major seaports; their work was not only conjuncturally influenced, but could actually fluctuate from day to day. Thus, the general class of shipyard maintenance workers who in Australia became known as "painters and dockers" were largely employed on as casual a basis as the watersiders themselves. ${ }^{9}$ The impact of this casual nature of employment cannot be stressed enough. As Phillips and Whiteside observed, "[t]he habits and beliefs which made up the docker's culture of work were inseparable from the casual nature of employment". ${ }^{10}$ The impact of this casualness was reinforced by the fact that most maritime labourers lived close to their place of work in denselypopulated and overwhelmingly maritime precincts and quarters. ${ }^{11} \mathrm{Al}-$ though as yet no quantitative study has been made of the subject, it also seems reasonable to accept that many dockers had served at sea before settling down ashore. Thus, despite all divisions a firm social basis existed for massive industrial action which could unite many different groups of dock labourers and for the cooperation which often and easily existed between dockers' and seamen's unions. This cohesiveness was expressed in the massive support for the several great maritime strikes, in which existing social and workplace differences were effectively transcended by collective solidarity. There was, certainly, less direct unionist rapport between these two groups and shipyard workers, but as the latters' working and living conditions - as well as their employers - were often comparable or closely related to those of the port transport workers and seamen, their industrial behaviour tended to show very similar tendencies.

${ }^{8}$ See R. C. Miller, "The dockworker subculture and some problems in cross-cultural and cross-time generalizations", Comparative Studies in Society and History, 11 (1969), pp. 302-314, and also Bruce Nelson, Workers on the Waterfront, Seamen, Longshoremen, and Unionism in the 1930s (Urbana-Chicago, 1988), ch. 1.

${ }^{9}$ Issy Winer, With Banner Unfurled: The Early Years of the Ship Painters and Dockers Union (Sydney, 1983).

${ }^{10}$ Phillips and Whiteside, Casual Labour, p. 271.

"For an interesting and quantitative discussion of this point see Sewell, Structure and Mobility, pp. 109-120. 
Second, as Kerr and Siegel have demonstrated, ${ }^{12}$ seamen and dockers were, with miners, the occupational group most likely to be involved in strike action. While this suggests that there was something inherent in their work situation conducive to militancy, it is also true that through the large number of massive strikes during the pre-Great War period maritime labour played a clearly visible role in industrial conflict and the class struggle. Moreover, the impact of their militancy, i.e. their propensity to take strike action, rapidly transcended the confines of their immediate work place as the stoppage of maritime work affected shipping, trade and finance of the whole nation. In turn, their economically strategic location may well have fostered their militancy.

Third, as maritime labour constituted a leading sector of the working class of the port cities in which they worked and lived, it tended to have a significant impact on the overall labour scene of those urban centres; and as, in turn, the major seaports of this era also were amongst the largest urban centres of their countries, their actions often had significant national repercussions. Fourth, because of their particular position in the national economic structure, as their function was not directly related to production but rather to a particular link in the total chain of transport infrastructure, maritime workers and unionists often were active in forming alliances with unions in adjacent fields. Moreover, and not unrelated to this factor, numbers of their leaders became prominent in the union movement in general as well as in politics, both in the national and international arenas. Fifthly, because of the international nature of shipping and trade, from a very early point syndicalist contacts were established between seamen's and dockers' unions in different countries. In consequence, maritime unions played a very distinct and important role on the international scene, as exemplified by, for example, the foundation of the International Transport Workers Federation or the maritime program of the International Labour Office.

The article will specifically investigate which forces shaped the working conditions of maritime workers, how they attempted to improve these conditions and with what effects they confronted their employers. At the heart of this analysis must, of course, lie the immediate industrial battleground of the maritime professions and occupations themselves: the ships, wharves, docks and shipyards of the international economy with their workers and bosses, employees' and employers' organisations. It is here that the fundamental, "internal", dynamics of the maritime labour movement originated, that one can find the issues that moved the men to strike and the conditions (including the nature and effect of the bosses' counter-

12 C. Kerr and A. J. Siegel, "Interindustry Propensity to Strike", in A. Kornhauser et al. (eds), Industrial Conflict (New York, 1954), pp. 186-223. 
vailing strategies) that shaped their objectives and their militancy, i.e. their apparent willingness and propensity to strike. A crucial aspect of the analysis must be to assess the relationship between workers and their union leaders - a subject of particular importance, both in the light of the recent debate on that question ${ }^{13}$ and the very complexity of that relationship. Indeed, while the militancy of the members always made them ready to be called up or to explode into spontaneous action, union leaders were often inclined to pragmatism and anti-militancy. The tensions implicit in such situations could be sublimated in membership acquiescence of charismatic or otherwise effective leadership or find expression in a range of alternative actions, including informal attempts at job control, wildcat strikes and, ultimately, the overthrow of the existing leadership and its replacement by leaders with pronounced radical ideologies. The literature has offered many possible explanations for the increasingly pragmatic policies adopted by the union leadership, ranging from the bureaucratisation, which could often be observed in German union hierarchies, to genuine disputes about strategic and tactical options. Thus it is imperative to consider the motives, ideology and general world view of union leaders, as these might differ markedly from the aspirations, objectives and interests of the members. In particular, significant differences of outlook could exist between members and leaders about the very position and function of their union, when the latter attempted to implement policies which their followers perceived as conflicting with their own forms of job control and industrial autonomy. This did not necessarily mean that the leaders identified their own interests with those of their employers, but the survival and effective functioning of their unions was often based on a more accommodationist approach to the problems and conflicts of the work place than the rank-and-file members were willing to contemplate.

Whatever the exact causes in each instance, the fact remains that maritime unionism after its rapid rise at the end of the 1880s always contained a fundamental internal contradiction between a militant tendency, on the one hand, and a more pragmatic or accommodationist line, on the other. While the former was, inherently, anchored in the rank-and-file membership, the latter was mainly, if not exclusively, inspired by its leadership. A factor of additional importance was that several union leaders had not themselves worked in the profession they represented. In colonial areas such as India trade unionism amongst largely illiterate workers would have been largely illusory, if educated and experienced outsiders such as N. M. Joshi (the "father of Indian trade unionism") or Mahomed Daud had not

13 Jonathan Zeitlin, “ 'Rank and Filism' in British Labour History: A Critique”, International Review of Social History, XXXV (1989), pp. 42-61, and discussion by Richard Price, James A. Cronin and, again, Zeitlin, in ibid., pp. 62-102. 
taken a leading role, ${ }^{14}$ but also in Europe, America and Australia whitecollar leaders were numerous, as the examples of Aristide Briand and Billy Hughes show. It was only too natural for such ambitious men, once they transcended the boundaries of their original constituencies, to subordinate the interests of their members to the requirements of their political careers. Thus, the main argument of the article will be that maritime labour contained within itself a fundamental and never-ending dialectic conflict between militancy and pragmatism.

Also the broader impact of maritime labour and unionism will be briefly discussed. This will entail tracing the relationship of maritime labour with the broader labour movement of their nations through alliances with other unions and membership of more general unions and national organisations as well as its impact on the national political scene. Besides tactical and more permanent organisational alliances it will be important to consider the ideological implications of maritime militancy. Although the adoption of communism by some waterside unions was not to come until after the Great War and the Bolshevik Revolution, there were already previously significant instances of the "industrial militancy" of maritime unionists being transformed by radical, syndicalist, leaders into support for radical political ideologies; the exact nature of these could, of course, differ from country to country according to the interplay of local circumstances with the international development and diversity of socialist ideology. The assessment of the historical importance of maritime labour must, of course, be based on the consideration that its articulation with its wider environment at the national and international levels involved both direct and mediated interactional processes, through which it received as well as transmitted influences, ideas and power.

\section{Industrial action and strategic dilemmas}

Although Kerr and Siegel in their analysis covered the years 1910-1945, there is sufficient evidence to suggest that maritime labour also during the preceding forty years or so displayed remarkable militancy and that shipyard workers were, similarly, frequently involved in strike action. During the half century or so from 1870 several periods with particularly intensive strike activity can be recognised. After the organization, in the 1870 s, of the first maritime unions and concerted action in all major English ports between 1879 and $1881,{ }^{15}$ a first massive wave of strikes hit the docks of the

${ }^{14}$ Frank Broeze, "The Muscles of Empire-Indian Seamen and the Raj 1919-1939", Indian Economic and Social History Review, 18 (1981), p. 66.

is John Lovell, British Trade Unions (London, 1977), p. 16. 
world between 1889 and 1896, with particularly bitter conflicts in ports such as London, Liverpool, Glasgow and St. Nazaire (1889), Hamburg and the ports of eastern Australia and New Zealand (1890), Hull and Nantes (1893), Manchester (1895), Antwerp, Rotterdam and Hamburg (1896). Then came a time of relative calm, punctuated by strikes in Genoa (1900), New Orleans, Bremen and Amsterdam (1903), Russia (1903 and, again, 1905), Hamburg (1906), Belfast, Trieste, and, again, Nantes (all in 1907), until, in a second wave of unrest, in 1911 all English ports, Antwerp, Rotterdam and Amsterdam struck. Two years later new outbreaks in Hamburg and New Zealand followed, while 1914-1915 witnessed a stoppage of many months at Genoa. Both during and after the Great War great strikes occurred in virtually all major ports; those in Spain and the German port cities of Kiel, Hamburg and Bremen were perhaps the most spectacular but by no means the only ones; even at Fremantle, during the lumpers' strike of 1919, a fatal casualty occurred.

Maritime strikes could not fail but be highly visible. In consequence of the extreme labour intensity of much of port and ship's work, they always involved large numbers and, with most workers living closely together in the vicinity of their job (the main exception here were the workers in the newly constructed free port of Hamburg, who had had to move to new living quarters located in the eastern zone of the city), their stopping work could easily take the physical appearance of a localised general strike. As trade and shipping stagnated or stopped altogether, many other employers and workers were directly affected. In many cases, as the Great London Dock Strike of 1889, the Maritime Strikes of 1890 in Australia and New Zealand or the Nantes strike of 1893 demonstrated, the industrial action of maritime workers had an impact which despite their apparent isolation from other economic sectors far transcended their own immediate boundaries. Mutatis mutandis, very much the same can be said for the naval proletariat. It is no coincidence that the decisive action in the unleashing of both the Russian and German Revolutions in 1917 and 1918 lay in the mutinies of the sailors of the two imperial fleets at Kronstadt and Kiel or that the mutiny on the Potemkin has become the symbol of the revolutionary spirit of the Russian people in 1905. The victory of the Bolsheviks in what became the Soviet Union, in turn, has had a powerful influence on many maritime unions throughout the world. It brought a strong impetus to their more radical wings and members who in some cases broke away from their unions and in others gained control over existing institutions. Such communist control over the dockers' and seamen's unions could in the 1920s be observed not only in an otherwise solidly capitalist society as Australia, where political communism was (and still is) utterly ineffective, but most especially in many European colonies and other countries of what later was to be called the third world. ${ }^{16}$ 
In explaining the varying propensities of different industrial groups to resort to the strike weapon, Kerr and Siegel considered, above all, the industrial and social structure of each group. They identified three circumstances, in particular, as being responsible for militancy: homogeneity of working conditions and occupational categories; isolation from the remainder of society through a lack of social mobility and a certain extent of cultural and geographical segregation; and, closely related to the previous two circumstances, a capacity to create and sustain cohesion within the group. Waterside workers and seamen in their port districts and sailortowns fitted as neatly into this socio-industrial scenario as the miners inhabiting their characteristic communities; shipyard workers, especially those with few or no skills, fall very much into the same categories. Others have, more specifically, tended to find their explanations in the working and living conditions of maritime labourers and the social and psychological attitudes which resulted from these conditions for the explanation of perceived militancy. Extrapolating from Miller's industrial sociological model of a dockworkers' subculture, one should then emphasise the casualness of much of maritime labour and the "casual frame of mind" which accompanied it, the physical hardships and dangers of working on and with ships, the appalling living conditions in dock areas and aboard ship, low wage levels and other unfavourable employment conditions, and the strong solidarity and mutual loyalty amongst the workers. There is no space in this paper to provide detailed descriptions of these material and psychological conditions, but there can be little doubt that all these factors constituted mutually reinforcing and powerful sources of discontent and militancy; although not all dockers, seamen and shipyard workers may have perceived this with equal clarity, they worked at the cutting edge of class antagonism and conflict.

To this list I should, with emphasis, add the sharpness in the relationship between workers and bosses which went far beyond disputes over purely industrial matters such as job control, working hours, wage levels, the number of daily call-ups, etc. The managers and owners of docks and wharves, whether they were public authorities, private companies, stevedores or shipowners, often had a callous disregard for the safety and welfare of the men they employed. Even if amongst stevedores elements of previously-held corporate beliefs of mutual support still existed and conditions

${ }^{16}$ See, for example, John Ingleson, "Life and Work in Colonial Cities: Harbour Workers in Java in the 1910's and 1920's", Modern Asian Studies, 17 (1983), pp. 455-476, and Alfred W. McCoy, "The Iloilo General Strike: Defeat of the Proletariat in a Philippine Colonial City", Journal of Southeast Asian Studies, 15 (1984), pp. 330-364 (dealing with 1930-1931); any chance of Communists taking control over the dock workers of Shanghai, however, was destroyed by the powerful triad "Green Gang”! (H. J. Lethridge (ed.), All About Shanghai (Hong Kong, 1983), pp. xii-xiii.) 
were not always uniform throughout each port, overall the situation had dramatically shifted. As the Melbourne wharfie Tom Hills told it, "Class war was seen at its most ferocious on the waterfront", ${ }^{17}$ and often the belief was held by the men that their bosses worked on the principle that, while a parcel of damaged cargo could not be replaced, an injured worker could. ${ }^{18}$ Of particular importance in this respect was the rise of the large liner companies. It has, of course, often been remarked how much their large and highly-capitalised fleets (the Hamburg-America Line, for example, already by 1900 worked with a capital of almost 140 million Mark, or c. $£ 7$ million) contrasted with the far more diffuse ownership of far cheaper sailing vessels. Naturally, this made the big shipping lines far less inclined to compromise with their staff while it also sharply widened the gulf between managers and men. But in order to understand the visceral and often also deep-seated ideological hostility of many shipowners to maritime unions it is even more important to stress the specific nature of liner shipping. Sea transport as a service was only produced when ships moved and, by contrast to the products of industrial or mining enterprises ashore, could not be stored in the hope of negating or at least alleviating the crippling impact of stoppages. Moreover, as liner companies operated on fixed schedules - as also opposed to sailing ships and tramps, whose more leisurely movements with bulky and cheap cargoes often allowed them to be regarded as convenient storage facilities - and carried relatively valuable (and often also perishable) cargoes, any interruption of their routine struck twice as hard.

Hence, acting out of a mixture of intrinsic anti-union ideology and the need to produce returns on the vast sums invested in their fleets, the leaders of the big liner shipping companies were often unwilling to recognise the legitimacy of the port workers' unions or to accede to their more specific demands. As was shown in the great Hamburg strike of 1896-1897, they keenly turned a wage issue into a pure power conflict. The Maritime Strike of 1890 in Australia and New Zealand may not have been provoked as a determined attempt by the shipowners to break the dockers' and seamen's unions, but this objective was soon adopted once the conflict had broken out. The big shipowners, moreover, organized themselves into extremely powerful and aggressive combinations such as the Shipping Federation or the Verband Deutscher Reeder. Saville has identified the Shipping Federation, in which the leading liner shipping companies of London (above all, the P \& O, British India, Orient Line and the New Zealand Shipping Co.)

17 Wendy Lowenstein and Tom Hills, Under the Hook, Melbourne Waterside Workers Remember 1900-1980 (Melbourne, 1982), p. 6.

${ }_{18}$ Malcolm Tull, "Blood on the Cargo: Cargo-Handling and Working Conditions on the Waterfront at Fremantle, 1900-1939”, Labour History, 52 (1987), pp. 15-29. 
combined in 1890, as the most ferocious of the employers' organizations of the period. ${ }^{19}$ With the concentration of liner shipping into an ever smaller number of closely related companies, often possessing considerable connections with, on the one hand, overseas trade and banking and, on the other, the shipbuilding and repair industries, its accumulated industrial strength gave it additional confidence that no challenges needed to be feared or tolerated. As the Hamburg radical lawyer and short-time "social director" of the Hamburg-America Line, Siegfried Heckscher, observed, "No one, who knows how sharp the confrontation in Hamburg is between employers and workers, will be surprised to learn that the shipping companies refuse to accept the seamen's union." ${ }^{20}$ Moreover, employers often were able to recruit large numbers of non-union labourers and, as a rule, could count on police, i.e. government, protection for those who were willing to work; thus, physical strike-breaking only served to further harden the divisions between labour and capital. In short, maritime workers lived in a state of almost permanent, if often latent rather than open, hostility towards their employers and the political system within which they operated. This militancy could be abated temporarily or, in the absence of effective unions, even over long periods of time, but never eradicated. In consequence, the potential for massive strike activity was never far beneath the surface.

It is not difficult to demonstrate empirically as well as deductively that militancy was bred by the very working conditions of maritime labour and that this militancy was a fertile breeding ground for radical syndicalists or revolutionaries. This was shown when Albert Ballin, the Generaldirektor of the Hamburg-America Line, in a desperate attempt to cram more passengers on the giant passenger liner Imperator and thus make this giant vessel operate profitably, changed its design and drastically reduced the accommodation of the ship's crew. "Wen kann es überraschen", commented Heckscher later, "dass die Heizer- und Stewardlogis auf den grossen Luxusdampfern Brutstätten anarchistischer, bolschewistischer Verzweiflungsideeen sind!" ["Who can be surprised by the fact that the rooms of the firemen and stewards on the large luxury liners are breeding grounds for desperate anarchic and bolshevik ideas!"] ${ }^{21}$ In sharp contrast to the

19 John Saville, "Trade Unions and Free Labour", in M. W. Flinn and T. C. Smout (eds), Essays in Social History (London, 1975), p. 264. While the P \& O and British India clearly were the powers behind the scenes of the Shipping Federation, its long-standing leader was Orient Line's director, Sir Thomas Lane Devitt, whose main public function was to promote various sail-training schemes and, with that, popular ideological support for Britain's merchant marine.

${ }^{20}$ Siegfried Heckscher, Die Lage der in der Schiffahrt Hamburgs beschäftigten Arbeiter (Berlin, 1903), p. 241.

${ }_{21}$ In a review of Bernhard Huldermann's biography of Ballin (Berlin, 1922), copied in 
desperation and militancy of the men, however, maritime unionism often appeared in a guise which seemed to belie such militancy and the resulting political radicalism, as it included a willingness to accept the existing system and to prefer negotiation and arbitration. At times, union leaders even aimed to avoid strikes and, indeed, join the bosses in the pursuit of the status quo or the making of agreements which the men might be opposed to. This attitude, it should be emphasized, must not be mistaken for the temporary expediency and tactical finesse which many unions, including those with anarcho-syndicalist leanings, employed whilst they prepared themselves for the ultimate general strike; it was the firm expression of the re-orientation of strategy and ultimate objectives within the politico-economic order of the day.

This tendency can be seen exhibited in the overwhelming support in Hamburg in 1918 for the SPD as opposed to that for the USP, or the absence of the National Union of Seamen, as the only major union, from the British General Strike of 1926; in the strong support from Indian seamen's unions after 1945 for the socialist Hind Mazdoor Sabha rather than for the Communist Party of India; and in the reformism which characterised the Australasian Waterside Workers Federation and the Federated Seamen's Union of Australia from the early 20th century to 1917 before their leaders were removed and shortly afterwards replaced by communist leaders. Conversely, this pragmatism is observable in the political careers of so many maritime trade-union leaders who were solidly reformist, became "Lib-Labs" or shifted even further across the political spectrum, such as Aristide Briand, Billy Hughes, Havelock Wilson, Ben Tillett, James Sexton, or the New Zealander J. A. Millar ${ }^{22}$ The same reformist attitudes often dominated the collectivity of port city workers, amongst whom the port workers themselves played a dominant role. Although strongholds of socialism or trade-union militancy, they often appeared to lack the will to challenge the existing order and, despite occasional agitation and rhetoric outbursts to the contrary, were solid adherents of the centrist or reformist sections of their national political and union organisations. Hamburg's parliamentary representation in the Wilhelmine Reichstag, as exemplified by August Bebel and Carl Legien, eloquently expressed this pragmatic leaning. ${ }^{23}$ Legien, in particular, as Hamburg's and Germany's "Oberhaupt der Gewerkschaftsbürokratie", after the Great War became the "Initiator

the diary of Johannes Merck, formerly financial director of the H.A.L. (Staatsarchiv Hamburg, Familienarchiv Merck, II 8, 2b, p. 203).

22 To this list could even be added Tom Mann in his pre-Australian phase, when he in 1896 stood as an almost successful candidate for the I.L.P. in the North Aberdeen by-election.

${ }^{23}$ Sima Liebermann, Labor Movements and Labor Thought. Spain, France, Germany and the United States (New York, 1986), pp. 126-134. 
der 'Arbeitsgemeinschaft' mit den Monopolherren". ${ }^{24}$ This does, of course, not mean that Hamburg's maritime labour was uniformly reformist, as can be seen by the very facts that its shipyard workers were the first to support the Kiel mutineers in November 1918 and that the leader of the KPD during the Weimar Republic and two-time presidential candidate, Ernst Thälmann, as Legien before him, was a Hamburg transport worker - with bad memories of a voyage he had made in 1907 as a fireman on a HamburgAmerica Line steamer to the United States. Although it is obvious that one cannot automatically equate individuals and their constituencies in either politics or unionism, Legien's and Thälmann's location in Hamburg would appear to be of much more than incidental significance: it shows the concurrent and conflicting existence of radical (in this case political-revolutionary) ideology and pragmatist accommodation within the heart of the port city's body of workers and unions. How can this apparent contradiction be explained? And what broader consequences did it have?

\section{Britain and Australasia}

Two factors must stand out, when one considers the reasons for the pragmatism of many maritime unions. First, the strength of the employers and their organisations, which simply made it impossible to continue with or to embark on confrontational strategies and, secondly, a recognition on the part of most of the workers, but even more so, their leadership, that ultimately the best interests of the unions lay in working with the employers rather than in pursuing futile radical or even revolutionary strategies. The aggressiveness and concerted opposition of the big shipping companies has already been stressed; what is important here is that they, on the whole, had not only the incentive but also the means to successfully fight the unions and reduce them to either ineffective or compliant instruments. This strength had been slowly developed during the 1870 s and 1880 s, when the structure of the shipping industry gradually changed with the transition from sail to steam and, even more importantly, the remarkable enlargement of scale and concentration of power in the liner shipping sector ${ }^{25}$ Moreover, in most countries the early unions, often specialised and founded in favourable times, achieved some gains and in Germany, where between 1878 and 1890 all socialist organisations had been outlawed, no major test of force as yet had taken place. Indeed, the great London Dock Strike of 1889 , which

${ }^{24}$ J. S. Drabkin, Die Entstehung der Weimarer Republik (Cologne/Berlin, 1983), p. 71.

${ }^{25}$ A good collection of essays on this stage of world shipping can be found in Tsunehiko Yui and Keiichiro Nakagawa (eds), Business History of Shipping, Strategy and Structure (Tokyo, 1985). 
brought labour unrest in the capital to new heights of intensity and in the number of workers involved, seemed to demonstrate that a "new union" of unskilled labourers could as effectively as any other stand up against the bosses. Not only was the ideologically mixed coalition of strike leaders, including Ben Tillett, John Burns, Tom Mann and Will Thorne, able to hold out for the full "dockers' tanner" and recognition of the Dockers' Union by the shipowners, but their success led to the formation of new unions and the strengthening of others. Moreover, the widespread sympathy the strikers received both in Britain from middle-class London and members of the establishment (including the mediator Cardinal Manning, whose family were London merchants and even counted a dock director amongst its members) and, especially, in Australia, created the conviction in the minds of many that permanent progress had been made. It was easily overlooked that only the large funds remitted from Australia had helped the dockers to sustain their strike, that it was truly exceptional that no significant violence had marred the indeed impressive record of responsibility and public relations built up by the strike leaders, ${ }^{26}$ and that the shipowners as much as the dockers themselves bitterly attacked the archaic and utterly incompetent dock companies. Sir Thomas Sutherland, the leader of the $\mathrm{P} \& \mathrm{O}$, at whose office the shipowners met, at one stage even went so far as to mischievously suggest that shipowners and dockers fought for the same cause.$^{27}$ As events soon were to show, nothing, of course, was further from the truth.

The big London shipping companies (especially the three great "East of Suez" companies: P \& O, British India and Orient Line) made use of the defeat of the dock companies to force them to adopt managerial changes. These, for the first time, gave the shipowners considerable power in the handling of cargoes. At the same time the latter formed the Shipping Federation, in which from the beginning Sutherland's $P$ \& O played the leading role, in order to concentrate their forces and have a weapon to defeat the unions in any future confrontation. As their destruction of the Wapping section of the Dockers' Union, in 1891, showed, the union movement found it difficult to remain united in other than extreme circumstances. ${ }^{28}$ The first great opportunity for the Shipping Federation came at Hull in 1893, where after seven weeks the combined seamen and dockers unions were crushed. Significantly, Tillett and Havelock Wilson were unable to rescue anything from the ruins in terms of support for their reformist approach. Indeed, in the judgement of its historian, Raymond Brown, the

${ }^{26}$ To the many well-known testimonies may be added that of Captain William Marden, the London manager of the West Australian Shipping Association: letter to WASA, 30 August 1889, in Battye Library, Perth, WASA (2478A), file 55.

$n$ John Pudney, London's Docks (London, 1975), p. 124.

${ }^{28}$ Lovell, Stevedores and Dockers, pp. 116-117. 
outcome of the strike not only marked the conclusion of the first phase of the new unionism on Britain's waterfront, but also set back unionism in Hull for well over sixty years. ${ }^{29}$ With this defeat came a general crumbling in the membership strength of the very unions which had triumphed in London, where in the meantime the shipowners, successfully exploiting both the many divisions existing within the capital's maritime workers and the impact of the economic depression, had gradually been able to turn work conditions their way. During the depression of the early 1890 s and beyond, maritime labour languished without effective representation and the only avenue open to their unions, if they wanted to survive, was to fall in with the employers' views. Havelock Wilson's National Sailors' and Firemen's Union was decimated, although, significantly, the remaining handful of members were characterised by "aggressive militancy". ${ }^{30}$ It was these circumstances which induced Mann to contemplate a parliamentary career and, above all, shaped James Sexton's outlook, when he in 1893 took over as General Secretary of the National Union of Dock Labourers, a position he was to hold until its last days in 1921 . He became firmly anti-activist and, instead, embarked on an ambitious career in the union movement and, subsequently, local and national politics (although it was not until 1918 that he entered the Parliament), during which he steadily shifted to the right wing of the labour movement.

While Sexton at Liverpool had some room for manoeuvre, as the Liverpool steamship owners (partly because of their greater number and variety and partly because of the geographical dispersion of their wharves over the waterfront) were far less effectively united than their London colleagues, Ben Tillett had a much more difficult task at London. As noted above, already in 1891 the Shipping Federation had broken the power of the Wapping section of the London's organized waterside labour, and during the following years it, and the other employers linked to it, gradually withdrew their recognition from the Dockers' Union. By 1899 Tillett was ready to follow the example set in Australia and New Zealand and to move, at the T.U.C. Congress of that year, for the acceptance of compulsory arbitration, a strategy which would at least force employers to deal with the workers. ${ }^{31}$ Although various unions gave him support at that and subsequent congresses, the T.U.C. as a whole never became sympathetic to the idea, as the leading (skilled) unions felt they already had sufficient industrial power to force employers to negotiate. As a rapidly growing number of labour leaders recognized, especially after the Taff Vale decision, the only

29 Ronald Brown, Waterfront Organisation in Hull, 1870-1900 (Hull, 1972), p. 88.

30 Basil Mogridge, "Labour Relations and Labour Costs", in S. G. Sturmey (ed.), British Shipping and International Competition (London, 1962), p. 284.

${ }^{31}$ Lovell, British Trade Unions, pp. 35-36. 
remaining alternative was to provide the union movement with a parliamentary wing. While Tillett himself had served already about a decade at Westminster, Sexton strongly supported the creation in 1900 of the Labour Representation Committee at Liverpool. ${ }^{32}$

With their support for parliamentary action and, in the case of Tillett, compulsory arbitration, the British maritime union leaders firmly turned their back on militancy; Tom Mann strengthened his state socialist views, but finding no outlet for them in Britain, he left in 1901 for Australia. Ironically, it was Australia (and, even more, New Zealand) which had already preceded Tillett down the road to parliamentarianism and compulsory arbitration. Economic and geographical conditions at both sides of the Tasman had favoured the various maritime unions since their foundation in the early $1870 \mathrm{~s}$. The seamen had been the first to federate individual colonial unions into a Federated Seamen's Union of Australasia, which also included New Zealand, and during the years leading up to 1890 all unions had not only made significant gains but also appeared well on the way to achieving a closed shop. The turning of the tide came, dramatically, in 1890, when industrial disputes in several sectors virtually simultaneously came to a head, and seamen and waterside workers in Melbourne, Sydney, Adelaide, Brisbane and New Zealand came out on strike in support of the Maritime Officers Union. No doubt buoyed by memories of the recent success of the dockers in London and the wide-spread support in Australia for their English colleagues, the strikers and their leaders far overestimated their ability to hold out against well-resourced shipping companies in a declining employment situation. When the police came out to protect non-union labour (used to carry wool to the Sydney wharfside) their position crumbled. Altogether the Maritime Strike lasted some two months, and ended in the complete ruin of the participating unions. In New Zealand, where a Maritime Council had bundled the forces of seamen, dockers and miners, the story was identical. However, it also led to a total change of direction for the labour movement as a whole, which was reinforced after further defeats for shearers and miners. A two-pronged strategy was now adopted: the parliamentarization of the labour movement (as early as after the election of 1891 in New South Wales it held the balance of power) in order to capture political power in the state, and to press for a system of compulsory arbitration. This would not only force the bosses to sit down with the workers, but also transfer the solving of conflicts to industrial courts where, it was hoped and expected, the industrial and financial muscle of the employers would be far less effective than in the market place.

\footnotetext{
${ }^{32}$ Eric Taplin, The Dockers' Union. A Study of the National Union of Dock Labourers 1889-1922 (Leicester, 1985), p. 133.
} 
While the particular circumstances of the time, with the Australian colonies moving towards Federation, considerably helped the Australian Labor Party - in particular, as it could happily go along with the wish for economic protection on the part of the majority of the employers and middle-class voters - it is likely that the politicization of labour would, also without that assistance, have been successful. New Zealand, which neither had the inclination to join the future Australian Federation nor considered adopting protectionist measures, as early as 1894 introduced its own Conciliation and Arbitration Act. The leader of its 1890 Maritime Strike, J. A. Millar, in 1907 became Minister of Labour in a Liberal government and, five years later, went so far to the right as to cross the floor against his own party and help form the Conservative government of Massey. The leader of the Wellington Wharf Labourers' Union, David McLaren, in the same year became Mayor of his city. As we shall see, such pragmatic political behaviour could not but result in massive mutinies amongst the rank-and-file membership. In Australia, very similar developments took place, with compulsory arbitration first introduced in New South Wales and, in 1904, by the Commonwealth government for federally registered unions. It was these developments which enabled astute organizers with political ambitions to bring new life to the maritime unions. While the Balmain Labourers' Union became the Federated Ship Painters and Dockers Union, R. S. Guthrie (later long-serving Senator) revitalized the seamen's union. More importantly, "that fiery particle" Billy Hughes, having undergone a hard political apprenticeship in the heart of Sydney's waterfront, in 1902 organised the Waterside Workers Federation. It was on the strength of his Sydney maritime constituencies, both union and political, that Hughes could embark on his political career, but of more importance here is that Hughes from the very beginning made the WWF a pragmatic, reformist and anti-strike instrument. He not only believed in the arbitration system, but also accepted that capitalism only needed steady reform brought about by non-violent means. ${ }^{33} \mathrm{He}$ and Guthrie in due course were to run dangerously out of step with their membership, but in the meantime the broader significance of the WWF in particular as Hughes' power base and, in turn, its support through his policies for the politico-economic system of the day, cannot be underestimated.

${ }^{33}$ Significantly, it was the failure of arbitration in an industrial dispute at Port Pirie, in 1908 , which converted Tom Mann to revolutionary syndicalism and the adoption of the strategy of the big industrial union. 


\section{Continental Europe}

While Great Britain, Australia and New Zealand may be regarded certainly with hindsight - as countries, where the revolution or even the revolutionary general strike would never come, the situation was different in European continental countries with sharply contrasting political cultures like France, Germany, Russia or Italy. But as the following section will show, such broad political and economic variations made little difference when it came to the development and historical dilemmas of maritime unionism. The continent displayed remarkable parallels to the AngloSaxon world in the incidence of militant industrial action and the subsequent internal tensions and conflicts of maritime labour as leaders backed away from radical positions to precarious accommodationism. But while employers and their allies exerted their inexorable pressure and pragmatism appeared to rule on the surface, deep below discontent gradually consumed at least some members' loyalties to their union leaders.

Hamburg provides an almost perfect model for these developments. As an early stronghold for socialism it was August Bebel's power base in both the SPD and, as its leader, from 1890 in the Reichstag. (Until the end of the Wilhelmine Reich all three Hamburg Reichstag members as well as the single member from adjacent Altona - then still Prussian - were, without exception, SPD.) It was no coincidence that the greatest 1 May celebrations in Germany in 1890, after the lifting of Bismarck's Sozialistengesetz, took place in Hamburg. Despite warnings from their political leadership large numbers of unionists took the day off and, although no violent scenes took place, employers the next day locked out some 20,000 workers. As Hund expresses it, this was a "joint attack by employers and the state on the organisation of the proletariat". ${ }^{34}$ Shortly afterwards the employers combined forces in the Arbeitgeberverband Hamburg-Altona, under the aggressive leadership of shipbuilder Hermann Blohm, while the unions had to lick their wounds and were in no condition to help their members during the dark days of the depression which hit Hamburg during the next five years (and which was considerably exacerbated by the cholera epidemic of 1892). Yet, as soon as economic conditions had improved, the winter of 1896-1897 saw the largest strike action yet at Hamburg, of over 16,000 waterside workers. Demanding improvements in pay and especially compensation for their travel problems resulting from their enforced removal from the inner dock districts when the new free port was built, they held out for just over two months under steadily worsening conditions until they had to unconditionally surrender. While the shipowners had been willing to make

34 Wulf D. Hund, "Der 1. Mai 1890”, in J. Berlin (ed.), Das andere Hamburg (Cologne, 1982), p. 129. 
some compromises, the Arbeitgeberverband overrode them and refused to tolerate even the smallest challenge to the authority of the bosses. Indicative of the dynamism of rank-and-file militancy, the strike had been totally spontaneous and called by the members against the wishes of their more realistic leaders.

Direct action, in fact, became virtually the only method the Hamburg maritime workers and their colleagues had in order to vent their frustration over the increasing bureaucratization and the pragmatic aloofness of their leaders. In January 1906, it was pressure from below, again, which forced the Hamburg SPD leadership to organise a general strike to protest against the intended alterations in the electoral law of the city-state, designed to reduce the potential number of SPD seats in its parliament, the Bürgerschaft. ${ }^{35}$ Port workers were even more active during the following 1 May demonstrations; the employers responded immediately with a ten-day lockout, recruitment of non-union personnel throughout Germany and the introduction of a licence system. ${ }^{36} \mathrm{~A}$ strike, in 1907, of 5,000 dockers who refused to accept the licence system, ended with their utter defeat; the system, indeed, proved to be such an effective method of worker control that what became known as Blohm's "Hamburger System" of fighting the Social Democrats was adopted by all large employers' federations. ${ }^{37}$ The large shipowners, in fact, did not need such tickets, as they refused to acknowledge the existence of the seamen's union and were able to enforce their position. The last chapter in this story was written, in the summer of 1913, by the workers of Hamburg's shipyards. Pressured by both the bosses and a deterioration in the business cycle, they rejected their union leaders' recommendations for further accommodation, went out on strike and were trounced. Feeling bitterly betrayed by their own leaders, they responded by leaving their organisations in droves and drifting towards more radical political movements. As Böge expressed it sharply, "eine Radikalisierung der Basis zeichnete sich ab" ["a radicalisation of the base became visible"]. ${ }^{38}$ Developments in the shipyards of Bremen were almost perfectly identical to those on the Elbe.

${ }^{35}$ Richard Evans, "Wahlrechtsraub, Massenstreik und Schopenstehlkrawall: der Kampf gegen die Wahlrechtsverschlechterung 1905-1906", in Berlin, Das andere Hamburg, pp. 162-180.

${ }_{36}$ Arnold Kludas et al., Hafen Hamburg (Hamburg, 1988).

${ }^{37}$ Klaus Saul, “' 'Verteidigung der bürgerlichen Ordnung' oder Ausgleich der Interessen? Arbeitgeberpolitik in Hamburg-Altona 1896 bis 1914", in Arno Herzig, et al. (eds), Arbeiter in Hamburg (Hamburg, 1983), p. 285. There is a great paradox here, indicative of the ambiguous position of union leadership, in the fact that in other circumstances (e.g. in Liverpool in 1912) the issuing of tickets was supported by some union leaders on tactical grounds as it could lead to a more or less closed-shop situation, while others regarded registration as the only effective long-term method to achieve decasualisation. 38 V. Böge, “" 'Werkzeug des Umsturzes' oder Instrument reformorientierter Arbeiter- 
The outbreak of the Great War, however, made Hamburg's workers for the time being rally behind the flag of the Burgfrieden. It was not until 1917 that the pent-up militancy and hostilities were to find their expression in strike action, and it was this seething discontent which made Hamburg's maritime labour in November 1918 reject its unions' demands for calm and help usher in the short-lived revolutionary period. It was then neither a matter of convenience nor a coincidence that the Workers and Soldiers Council, who took over power in Hamburg, established themselves in Ballin's office at the headquarters of the Hamburg-America Line. In the meantime, however, reformist union bosses like Legien and Störmer had fostered the pragmatism and ideological accommodationism which, within a week of the Revolution breaking out, made the workers decide not to abolish the existing institutions of the state and, instead, to work with them and the employers who controlled them. The militancy of the port waned as rapidly as it had risen and it was left to small groups of workers, who did not accept the abandonment of the revolutionary ideal and the political, social and industrial changes which they hoped it would bring, to maintain the radical élan by joining the KPD. As equally port-based as the Social Democrats, who by the 1920 s had more consciously than ever placed themselves within the free trade ideology which dominated Hamburg's business traditions and elite ${ }^{39}$ they embodied, in their small numbers, the sociological weakness yet ideological survival of the revolutionary fervour which could so easily be generated in the pressure-cooker situation of the waterfront's labour conditions. The strength of the commitment and the national significance of this relatively small section of Hamburg's working class was epitomised by Thälmann's subsequent rise to the leadership of the KPD. (The strength of this radical tradition was manifested when in March 1932 the world congress of the Internationale der Seeleute and Hafenarbeiter was held at Hamburg, and, indeed, is still present in the city, finding its expression, inter alia, in the Ernst Thälmann Gedächtnisstätte [memorial room] and the "alternative historical city tours" offered by the latter's organisers.)

The political situation in France prior to the Great War could, relatively speaking, hardly have been more different from those in Britain, Australia, Germany, or other neighbouring European countries, as the French working class was active in both the political and industrial arenas and revolutionary syndicalism was an established part of the socialist scene. Yet,

politik? Die Gründung der 'Volksfürsorge' in Hamburg 1912-1914", in Herzig, Arbeiter in Hamburg, p. 395.

${ }^{39}$ Axel Schildt, "Hanseatische Vernunft kontra Extremismus? Zum antifaschistischen Kampf der hamburger Sozialdemokratie 1929-1933", in Berlin, Das andere Hamburg, p. 271. 
mutatis mutandis, very much the same picture emerges, characterised by the rise of militant radicalism, syndicalist failure, and reformist-pragmatist leadership henceforth. This may be illustrated by the developments in the lower Loire towns of St. Nazaire and Nantes, a twin community with a comprehensive maritime industry based on overseas commerce, shipbuilding and steamshipping. Long before the rise of the modern shipyards in the 1880 s, there had been early strikes by the wooden shipwrights at St. Nazaire. Then, it was through the propaganda and organising work of the anarchist fireman Victor Cails as much as that of radical middle class socialists like Aristide Briand, Charles Brunellière (himself, ironically, a shipowner) and Fernand Pelloutier that the maritime workers of the Loire Atlantique became committed to the syndicalist struggle. Decisive in their turn away from parliamentarianism towards the general strike as their method to bring about the revolution, was a great strike, in AugustSeptember 1889 , in the Penhoët shipyard, which failed due to the intransigence of the employers and the brute force used by the gendarmerie on horseback..$^{40}$ As, moreover, the republican middle classes also came out strongly against Briand and his fellow union leaders, the latter began preparing for the general strike. Significantly, while Briand and Pelloutier gained strong support for their thesis that only the general strike could help the working class at the annual congress of the trade unions in $1892,{ }^{41}$ they, by contrast to the Allemanists, insisted on its peaceful course, "la révolution avec les bras croisés" ["the revolution with crossed arms"]. Nantes, with its maritime labour and radical leadership, became the pace-setter in the movement. The year 1893 was replete with industrial agitation and activity at Nantes and St. Nazaire, including a dock workers' strike which, at the very moment when it might have developed into a broader movement, was strongly repressed with police assistance. Thus the scene was set for the 1894 national labour congress at Nantes itself, where it was, after bitter debate, decided to adopt the general strike. ${ }^{42}$ "Its proponents argued that the general strike could be carried out relatively easily once workers in certain key industries - food and transportation - left their work." ${ }^{43}$

During the next fifteen years, the union movement built up its forces in preparation for the general strike, only, in 1910, to find it the ineffective weapon the political socialists had always maintained it was. Already three years earlier, however, the dockers of Nantes had suffered their defeat in a

40 Guin, Mouvement ouvrier nantais, p. 263.

${ }^{41}$ Ibid., p. 267.

${ }^{42}$ Patrick de Laubier, La grève générale en 1905. Le mythe français et la réalité russe (Paris, 1979), p. 33.

${ }_{43}$ Bernard H. Moss, The Origins of the French Labor Movement 1830-1914 (BerkeleyLos Angelos, 1976), p. 142. 
bitter and physical conflict, which cost one life as the result of a vicious police charge and lasted for well over a month. ${ }^{44}$ Precisely because of the strike's anarchic and potentially revolutionary nature, the Nantes bourgeoisie was all the more intent on squashing all resistance. To rub salt into the wound, the employers reduced the docker's hourly wage from $0.55 \mathrm{~F}$.fr. to $0.50 \mathrm{~F}$.fr. - while the strikers had demanded an increase to $0.75 \mathrm{~F}$.fr. and gave preferential treatment to the "jaunes", the members of the employer-controlled unions. By this time, the national government at Paris was built around the "sinister trio" Clemenceau - Briand - Viviani, ${ }^{45}$ each of whom had, once, been a revolutionary, or at least a radical, himself. The metamorphosis of Briand was all the more unpalatable for the maritime workers of the Loire Atlantique when he, later in 1907, visited St. Nazaire to open its new port. Their position under repression was made crystal clear, when Henri Gautier failed to have employer-controlled "jaunes" excluded from the local seamen's union (the Fédération d'Inscrits Maritimes) and another unionist received the maximum one year prison term for having lambasted Briand during his visit and castigated him for having forgotten his political origins. ${ }^{46} \mathrm{Henceforth}$, the future was with the reformism of the C.G.T., even if, as 1 May 1914 was to show, the militancy of the membership simmered only a short distance below the surface.

Analysis of maritime unions, their strikes and leaders, and place within the overall labour movement, in other areas and countries shows very similar features to those discussed above. The Russian dock strikes of 1903 at Odessa, ${ }^{47}$ Baku and Rostov failed, but being the first of their kind had the same magnetic effect the first great strikes in western Europe had had, and helped prepare the ground for the general strikes of 1905 which did threaten to engulf the whole country in revolution and were met with a mixture of repression and cosmetic concessions. The Belfast dock strike of 1907, similarly, brought the whole "city in revolt" (to adopt the image created by its historian), ${ }^{48}$ and was repressed with such ferocity that it produced an unprecedented police mutiny. It was, above all, the expression of the exasperation of the poorest of the city's workers. Under James Larkin's syndicalist influence Protestants and Catholics united in desperate mil-

44 Guin, Mouvement ouvrier nantais, pp. 345-356.

${ }_{45}$ Moss, Origins of the French Labor Movement, p. 359, quoting Le Populaire of 9 August 1908.

${ }^{46}$ Guin, Mouvement ouvrier nantais, p. 356.

${ }^{47}$ Patricia Herlihy, Odessa. A History 1794-1914 (Cambridge, MA, 1986), p. 93, and also Theodor $\mathrm{H}$. Von Laue, Sergei Witte and the Industrialization of Russia (New York-London, 1963), p. 256. In 1901 Odessa had been the scene of a smaller dock strike.

48 John Gray, City in Revolt, James Larkin \& the Belfast Dock Strike of 1907 (Belfast, 1985). 
itancy, but against the combined forces of the employers and the state (uniquely, even battleships were stationed in Belfast Lough) they were ultimately too weak. As at Nantes in the same year, and in Hull fourteen years earlier, the defeat of the Belfast dockers meant the destruction of organized labour in their city; tragically, the end of syndicalism also spelled the end to communal solidarity. ${ }^{49}$ The dock workers' strike in Austria's leading port city, Trieste, in the same year 1907, was similarly crushed and then followed by the establishment of a local employers' federation. ${ }^{50}$

In Belgium, the only country in Europe where this occurred, the general strike was used successfully by the union movement to extend the political franchise throughout the working class, but that did not diminish the incidence of dock strikes at Antwerp. These often paralleled those at Amsterdam and Rotterdam in the Netherlands which country had no such tradition of political syndicalism. These strikes were, generally, countered by employers and city governments with the same determination and effectiveness as those elsewhere. A factor of great importance, however, in the Low Countries, was the realisation by dockers and seamen that they could only agitate effectively if they were linked internationally. Not only did they have to face non-union foreign workers being ferried across the North Sea for strike-breaking purposes (as in 1896, when Rotterdam bosses had employed British seamen to defeat a strike of local dockers), but, much more importantly, they found it was impossible to strike effectively in one port, if the others continued to work untrammeled. The resulting push towards international cooperation came at a propitious time as the leaders of the hard-pressed British maritime unions (especially Wilson, Mann, Tillett and Johnson) were very much interested in exploring avenues to give their movement another pillar of support. ${ }^{51}$ On 27 July 1896, the first meeting of the committee of what was soon to be known as the International Transport Workers Federation was held. Amongst those present were the British leaders already named, and delegates from Hamburg, Holland, Belgium, France, Sweden and the United States. (In the latter country as yet no effective organizations of longshoremen and seamen existed, but the meeting sent Edward McHugh, of the Liverpool NUDL, to New York.) Such cooperation carried into the international sphere what, nationally,

${ }^{49}$ An interesting and contemporary parallel to the communal solidarity of Belfast's maritime workers is provided by the continued inter-ethnic cohesiveness of black and white longshoremen in the Dock and Cotton Council of New Orleans, especially in their bitter (but successful) strike of 1907 (Daniel Rosenberg, New Orleans Dockworkers: Race, Labor, and Unionism, 1892-1933 (Albany, NY, 1988), p. 181.

${ }^{50}$ Cattaruzza, “ 'Organisierter Konflikt' und 'Direkte Aktion", ", p. 346.

s1 It may be stressed here that attempts to find additional strength in imperial links with sister organisations in Australia and New Zealand, after the collapse of the maritime strikes in those countries, had all come to nought. 
had already often been achieved temporarily and on an ad hoc basis. Maritime unions, indeed, had already earlier been involved in alliances with unions in adjacent fields; in Australia and New Zealand, for example, where the coastal shipping industry was still a vital part of the countries' economic infrastructure, coal miners had, in 1890, joined the Maritime Strike in order to deny coal to the steamers (whose engineers, by contrast, had not stopped work). Other potential alliances lay in the direction of land-based transport and it is, of course, in this direction of creating alliances between maritime and railway workers that the I.T.F. experienced its most significant expansion; also on a national basis, general transport workers unions, which specifically included port workers, were to be a part of the future union movement.

By 1900 the I.T.F. had already a remarkable array of unions incorporated under its wings. About half its members were railwaymen, largely from Germany (Carl Legien headed the list of those present at the 1900 Paris Congress), Austria, Belgium, France and Spain; the maritime unions originated, above all, from Britain, Germany, France, Denmark, Holland and Belgium. ${ }^{52}$ The importance of this international network cannot be underestimated - if only, because, remarkably, it has survived the times and still fulfils a role of considerable importance. But also, at the time, it meant at least the potential for an international front, as well as the creation of channels of communications through which ideas could be transmitted and influence exercised. Of course, this could work both ways: against the full reformist weight of the German and British unions, which could not but help dampen revolutionary spirits, stood the more subtle and individual transmission of radical views and programmes. Tom Mann, until 1901 President of the I.T.F., in his many contacts with existing and new branches and maritime and other transport workers helped create connections through which alternative ideas could continue to flow.

After his return from Australia (where he, as noted before, had become converted to revolutionary syndicalism) and a brief visit to France in 1910 Mann achieved a combination of the bulk of Britain's dockers and seamen in the National Transport Workers Federation. This was both sound industrial strategy and, for Mann, the first step on the long road to effective syndicalism. ${ }^{53}$ When he returned to Liverpool, he found an explosive situation on his hands as the acquiescence of the dockers with their pragmatic leaders had worn paper-thin. When spontaneous action broke out and a general port strike commenced, he was moved immediately into the

52 K. A. Golding, 75 Jahre ITF. Zur Geschichte der Gewerkschafts-Internationale, die seit 1896 Geschichte macht (Vienna, 1971), pp. 7-9; see also Tom Mann, Memoirs (London, 1923), pp. 106-117.

${ }^{53}$ Henry Pelling, A History of British Trade Unionism (4th ed., London, 1987), pp. 134135 and 140 . 
leadership of the joint seamen-dockers committee. ${ }^{54}$ While it, initially, looked like the conflict might be settled soon, the militancy of the workers carried them further along the path of confrontation. In August 1911 a national general strike was called; for several days also all British railwaymen came out. In the end, making their move on the upswing of the business cycle, virtually all strikers made substantial gains. Not only wages were increased substantially, but in several ports joint boards were set up to provide a permanent machinery for negotiations between employers and employees. Implicit in the concessions gained was the recognition of the unions by the Shipping Federation, but there was by no means a closedshop; on the contrary, both unions and the Shipping Federation were preparing themselves for further confrontations when the Great War intervened. Despite all militancy of the men, however, the unions' leader at no stage challenged the existing public order and it is also possible to see the 1911 settlement as an, albeit hesitant, precursor to the remarkable wartime agreement between Havelock Wilson and the Shipping Federation of 1917 which set up the National Maritime Board.

The maritime workers of Liverpool and London were not the only ones who won in 1911: through the I.T.F. a far more widespread maritime strike had been called than ever before, with total strike action in Holland and Belgium, as well as on the British east coast. With the exception of Amsterdam, where employers in the hot summer of 1911 found it easy to recruit non-union labour from neighbouring fishing villages, ${ }^{55}$ international solidarity made the strikes successful. The colleagues from Hamburg, however, did not join, as could have been foreseen since they, in 1910, had dissolved their union and become a minority section in the accommodationist and bureaucratic Deutscher Transportarbeiterverband. But, even so, in their neutrality they at least prevented any German strike breakers from being recruited. The success of the maritime workers and railwaymen led to many significant changes in the British structure of trade unionism through the rapid expansion of general membership of the maritime unions and the amalgamation of the railway unions. In 1914, this syndicalist "trust formation" took another major step forward in the formation of the Triple Alliance between the T.W.F., the miners and the New National Union of Railwaymen. Typically, however, for its being created by leaders like Tillett and Wilson, it was not a revolutionary body or even an aggressively

54 Robert J. Holton, “Revolutionary Syndicalism and the British Labour Movement", in Wolfgang J. Mommsen and Hans-Gerhard Husung (eds), The Development of Trade Unionism in Great Britain and Germany 1880-1914 (London, 1985), p. 273; Phil H. Goodstein, The Theory of the General Strike from the French Revolution to Poland (Boulder, 1984), pp. 257-258.

55 J. M. W. Binnenveld and F. S. Gaastra, "Organisatie en conflict van een vergeten groep", Economisch-en Sociaal-Historisch Jaarboek, 35 (1972), p. 315. 
reformist one; above all, the Alliance (which was to come to grief in the cataclysmic days of 1921) was aimed at creating a body of concerted action, giving the impression of a good deal of common strength and purpose, but nevertheless leaving its members their individual freedom of action in a system of direct negotiations with their employers. ${ }^{56}$

\section{Militancy in extremis}

During the last few years until the outbreak of the Great War, the leadership of most maritime unions became increasingly pragmatic and moderate. In both defeat and success they had learned not only to recognize the limits of their power but also that, ultimately, their interests were significantly linked with those of their employers. This was not only because, ultimately, their jobs depended on their ports, shipping companies and shipyards maintaining and increasing their business in an increasingly integrated and competitive world, but also because unions could not function effectively without recognition by the employees. This, in turn, was predicated on the union leaders maintaining control over their members and channeling their grievances into more formal channels of negotiation and conflict resolution. While the workers themselves were not disinclined to follow effective leaders (some of whom may well have been charismatic as well) and acquiesce in their more pragmatic approach, they were nevertheless often less "realist" and their innate tendency towards militancy could at all times erupt in spontaneous strike action. Strikingly, in Liverpool minor spontaneous outbreaks of conflict continued, partly inspired by syndicalist influences from overseas ports. Similarly, a group of Rotterdam dockers broke away from their union, after a new collective agreement was reached in 1911. In Hamburg and Bremen, 1913 witnessed spontaneous and lengthy strikes of shipyard workers which revealed dramatic tensions between reformist union leadership and their far more militant members; the labour movement as a whole in both cities, in turn, showed itself equally bitterly torn. ${ }^{57}$ The challenge put by the workers was, nevertheless, perceived as being so serious that the Bremen Senate ordered the establishment of a permanent mounted police force. ${ }^{58}$

The most telling examples of militancy, however, occurred in New Zealand and Italy. It has already been recounted how the leaders of the maritime unions in New Zealand had gradually shifted to the right; in the

56 Lovell, British Trade Unions, pp. 45-49.

${ }^{57}$ Cattaruzza, “ 'Organisierter Konflikt' und 'Direkte Aktion' ”, pp. 344-345.

${ }^{58}$ Herbert Schwarzwälder, Geschichte der freien Hansestadt Bremen, vol. 2 (1810-1918) (Bremen, 1976), p. 553. 
course of time this created increasing opposition from their members who, with several other unions, became the centre of a strongly syndicalist minority within the trade-union movement, the Red Federation. Their platform very much resembled that of Tom Mann and squarely reversed their former belief in arbitration and conciliation: "To organise systematically and scientifically upon an industrial union basis, in order to assist the overthrow of the capitalist system, and thus bring about a co-operative commonwealth based on industrial democracy." 59 Although their new leaders still urged caution, the militancy of the men was such that a minor issue made them come out on strike. For about two months, from October to December 1913, 5,000 watersiders, 2,000 seamen, 4,000 miners and 5,000 others held out against their employers and the government. Serious riots erupted in Wellington, when special mounted constables (raised in agricultural areas; the strikers called them "Massey's cossacks") entered the city. In a country which only a few years previously had prided itself on being in the forefront of solving the conflict of capital and labour through imaginative socio-political experimentation, ${ }^{60}$ the Wellington Police Commissioner now issued the clear order: "If they don't go, ride over the top of them. ${ }^{\prime 61}$ It was arguably the most bitter and most violent union conflict the country ever witnessed, and brought utter defeat to both the maritime unions and the Red Federation.

While the New Zealand experience provides an almost "ideal-type" of the predicament and dilemmas of maritime labour, from $c$. 1910 the seamen's union in Italy offered a spectacle of uncompromising militancy in, both nationally and internationally, unique industrial circumstances. While Italy's dockers conformed to general patterns by being active members of the reformist socialist Confederazione Generale del Lavoro (the Genoa dockers, previously, had played an important role in defending the Chambers of Labour against the repressive policies of the Pelloux government), ${ }^{62}$ Italy's first seamen's unions by 1906 had been effectively destroyed by the shipowners. Between 1909 and 1911, however, they were reconstructed into an extremely powerful and effective body with, as one might aspect after the failure of moderate leadership, a strong syndicalist ideology. More importantly, the newly-founded Federazione Italiana dei Lavoratori del Mare was the only seamen's union ever to unite all seafarers from trimmers to ship's captains. This achievement was entirely due to its leader, Captain Giuseppe Giulietti, who combined ultra-patriotism with a social ideology

59 Roth, Trade Unions in New Zealand, p. 36.

${ }^{60}$ W. Pember Reeves, State Experiments in Australia and New Zealand (2 vols, London, 1902).

${ }^{61}$ Quoted in Roth, Trade Unions in New Zealand, p. 38.

${ }^{62}$ Goodstein, Theory of the General Strike, p. 96; Martin Clark, Modern Italy 1871-1982 (London, 1984), pp. 141 and 220. 
which successfully transcended the class differences aboard ship; as Webster expressed it, the basis of his views was more Mazzinian than Sorelian. ${ }^{63}$ (In view of these circumstances and Giulietti's friendship with D'Annunzio, it is not surprising that the mariners were to play an important role in the development of fascism in Genoa. Indeed, D'Annunzio seems to have regarded the pact with which he transferred control over the seamen's union to Mussolini as a test case of his ability to work with the new fascist government; by contrast, the socialist dockers union of Genoa in 1922 was eliminated by an invasion of fascist storm troopers. $)^{64}$ Giulietti, moreover, had excellent contacts with many socialist parliamentarians in Rome and high officials at the Ministry of the Merchant Marine, while his own social position approximated that of the shipowners themselves. He shrewdly directed his first action against the subsidised mail steam shipping companies, which were subject to a measure of political control from Rome, and played shrewdly on the pernicious influence, he claimed, German shipping companies had in that section of the Italian merchant marine. By dividing the shipowners he was able, in 1913, to achieve full success in his demands for better employment conditions. So much so, in fact, that during the next spring the independent shipowners, who could count on the support of Salandra (who, unlike his more pragmatic rival Giolitti, was not willing to tolerate such union victories), formed a united front and squarely challenged the seamen's union. The situation quickly deteriorated and soon over a hundred ships were lying idle at Genoa, while the city's dockers also came out on strike. The Great War broke out but the strike continued until April 1915, when Salandra forced the shipowners to accept arbitration; as he was pushing hard for Italy's entry into the war on the side of the Allies, he could not do without the support of Giulietti's patriotic seafarers who from August 1914 had been clamoring for Italy to attack Austria. ${ }^{65}$

\section{Conclusion}

In conclusion of this broad-brush overview five major findings may be put forward. First, the militancy of maritime labour was not a matter of local or even national circumstances, but a phenomenon which was international and sustained throughout the period. Because of the nature of their work maritime workers had found it more difficult to effectively organise in modern trade unions than most other professions and, in consequence,

${ }^{63}$ Webster, L'imperialismo industriale italiano, pp. 336-337.

${ }^{64}$ Adrian Lyttelton, The Seizure of Power, Fascism in Italy 1919-1929 (London, 1973), pp. 68, 82 and 95 .

${ }_{65}$ Webster, L'imperialismo industriale italiano, pp. 342-347. 
their major impact was not felt until late in the 19th century; ${ }^{66}$ the fact that Australia and New Zealand were far ahead in the national organisation of their seamen reflects the high level of development and coherent nature of their steamshipping industry more than anything else. Once a certain degree of mass union organisation was achieved, however, it became a matter of when rather than whether to strike. Significantly, the first wave of strikes, some also including shipyard workers, occurred world-wide in a narrow temporal band around 1890 . Whatever the specific and local issues involved in each strike, the underlying causes of the men's continued propensity to strike were rooted squarely in their working and living conditions which, as all contemporary descriptions and testimonies demonstrate ad nauseam, were sufficiently impervious to amelioration to chronically feed such militancy. As Nelson has recently emphasised in his study of the 1930s US westcoast, "the maritime workers' own subculture was a vital ingredient in the fuel that propelled them forward [. . . ] and it drew upon well springs that were deeply embedded in the historical experience of the waterfront labor force. This subculture was nurtured in the isolation of the sailortowns, in the harsh conditions of work aboard ship and along shore, in the encounter with the diverse ways of life in the world's port cities." ${ }^{67}$ Even if, particularly in Britain, older forms of specialist labour with privileged positions survived (and some workers occasionally struck for the protection of such sectional advantages and demarcation disputes) and the specific situation of some groups of port labour may have varied markedly, the great bulk of the workers were affected by very similar and comparable job conditions. The pivotal aspects of these conditions were the casualness of their employment and the fact that they could only too easily be replaced with non-union labour. The casualness of their labour could directly be related to men's militancy which, in itself, could become a way of life. In the words of the Liverpool dock labourers' organiser, James O'Connor Kessack, "The dockers were champion strikers - they were always in training: their work was casual." ${ }^{68}$ The men's living conditions, moreover, and especially the lack of any significant improvement demonstrated the failure of the "system" to satisfy their most basic demands. The many variations on this theme may well be summed up by the comment of the tattooed British sailor-king, George V, after his visit, in 1932, to Birkenhead, Merseyside's

${ }^{66}$ This is, of course, not to deny that previously no maritime strikes or protest had taken place; see, e.g., Simon Ville, English Shipowning during the Industrial Revolution (Manchester, 1987), pp. 104-105 and the references mentioned here.

${ }_{67}$ Nelson, Workers on the Waterfront, p. 273.

${ }_{68}$ Quoted in Eric Taplin, The Dockers' Union. A Study of the National Union of Dock Labourers 1889-1922 (Leicester, 1985), p. v. Cf. also Phillips and Whiteside, Casual Labour, pp. 271-272. 
shipbuilding distrct: "If I had to live in conditions like that I would be a revolutionary myself." ${ }^{69}$ These conditions and the sharp antagonism which soon existed between maritime labour and their employers who on the whole vigorously resisted their demands, made the men not only intrinsically militant but, under circumstances which could differ from country to country and also within individual countries, open to radical political and syndicalist ideas and ideologies.

Second, the adoption of pragmatic policies by maritime union leaders and the lack of strike activity during long periods did not necessarily mean that the general outlook of the men changed in any significant way. The crippling defeats incurred by the maritime unions dramatically reduced membership strength, forced the men to accept otherwise unacceptable conditions and shaped the realist policies of their leaders. Nevertheless, many maritime workers - inevitably, because the dynamism of their militancy was rooted in their working and living conditions and, to some extent, also the strategic place their occupations enabled them to hold in their national economies - never lost their potential for radical action and adherence to extremist ideologies. It thus remains to be explained why union leaders were prepared to adopt and follow policies which contrasted significantly with the feelings of their members. While it can be argued that in all workers groups and trade unions a natural tendency exists which can make them prone to becoming bureaucratized and to losing their militancy, the case of maritime labour over the forty years or so before the outbreak of the Great War shows that the shift to accommodationism resulted from a far more complex interplay of both internal and external forces. This is not to deny that, particularly in Germany, some bureaucratization did not occur or that not some individual maritime union leaders used their positions for their own purposes and particularly to co-opt themselves into the political system of the day. But, on balance, far more important was the realisation amongst the leaders that the vulnerability of maritime unions in their confrontation with the power and hostility of the shipowners and their allies - merchants, bankers and, more often than not, local and national authorities - required flexible and pragmatic leadership. It is difficult not to see the several national and international organisations of liner shipping companies $^{70}$ as particularly ferocious and effective instruments of employ-

${ }^{6}$ Kelly, Idle Hands, Clenched Fists, p. 65; significantly, no attention is paid to such issues in Harold Nicolson's semi-official biography King George V. His Life and Reign (London, 1952).

${ }^{2}$ In 1907, moreover, an International Shipping Federation was founded to counteract the influence of the International Transport Workers Federation and "to combat the growing forces of socialism and aggressive trade unionism" (Arthur Marsh and Victoria Ryan, The Seamen. A History of the National Union of Seamen (London, 1989), p. 53). 
ers' solidarity and, as the shipowners more often than not buttressed their self-seeking policies with an extremely strong anti-socialist ideology, the cutting edge of the class struggle. Determined to keep their capital-expensive fleet of steamers moving and virtually always assured of police or military support to protect their strike breakers, these shipowners had massive financial and other resources. It is true that, particularly in the early part of the period, the employers were not always totally united in their opposition to their workers, but overall the growth of companies like the $\mathrm{P} \& \mathrm{O}$ or the Hamburg-America Line and the establishment of bodies, such as Britain's Shipping Federation enabled them to exert enormous power. Thus they not only could prevent major defections from their own ranks but also, if they were not able to withhold recognition from unions, forced or at least induced union leaders to become reformist. ${ }^{71}$

It should, however, be stressed that such pragmatism on the part of union leaders was not just a matter of self-preservation. For many union leaders it was indeed clear that unions could only operate effectively if they established a working-relationship with the shipowners and that militancy might well only lead to further defeats. But they also realised that indiscriminate strike action could prevent the achievement of any real progress, particularly towards the elusive goals of union preference and de-casualisation. ${ }^{72}$ Some union leaders very specifically saw such a working relationship as the road to the closed-shop with considerable worker control over jobs. Havelock Wilson's long-term strategy, for example, aimed at achieving the establishment of a joint board for the recruiting of seamen and the conducting of negotiations and conciliation procedures with the shipowners. ${ }^{73}$ The mix of motivations and calculations about policy could differ from union to union, but the net effect was very much the same throughout the industry. As might be expected in such a situation, some union leaders, in being perceived to lean too much towards the employers' viewpoint, risked losing the confidence of at least some of their members. Others went further and, as Aristide Briand exemplified in his shifting across the political spectrum, transformed themselves into opponents of the workers they had once led. In many cases these shifts were already visible before the Great War, in others (like those of Hughes and Guthrie in Australia and, to a lesser extent, Sexton in Liverpool) it was precipitated over war-related issues.

${ }^{71}$ For a final example, relating to the Greek Panhellenic Seamen's Federation PNO in the early 1920s, see Kitroeff, "The Greek Seamen's Movement", p. 79. The "reformist leadership" of the PNO was unable to prevent its membership from joining the strike called by a small left-wing union which was ended by the intervention, at the cost of two strikers' lives, of government troops.

72 Cf. Lovell, “Sail, Steam and Emergent Dockers' Unionism”, pp. 248-249.

${ }^{73}$ Marsh and Ryan, The Seamen, pp. 59-60. 
Thus, third, sharp contradictions could exist between the outlook of reformist leadership and that of their militant members. While the tensions between union leaders and their rank-and-file could remain subdued for considerable periods, ultimately they were bound to erupt, particularly when pent-up frustration led to the adoption of radical political ideologies. Thus, leaders who shifted too far right on the political right or became too cautious or accommodationist ran the serious risk of alienating their members and losing control over their unions. As, for example, the strikes in Nantes and Belfast (both 1907) and New Zealand (1913) showed, they were unable to contain their members' militancy. Significantly, in view of the pragmatists' often more realistic assessment of the power of their opponents, these strikes were savagely crushed and'resulted in the total collapse of the unions involved. In the course of such spontaneous action or other crisis situation, moderate leaders could shift their position and follow the men's lead or be replaced by radicals. Depending on local circumstances, however, such radical leaders could, as happened to Tom Mann in 1911, be swept aside again; alternatively, they could establish a firm hold over the now firmly radicalised union (with, often, a sharply reduced membership). Although a detailed comparative study would be needed to collect sufficient evidence for such a judgement, it is inviting to suggest that these internal confrontations and conflicts between militancy and pragmatism were more profound in maritime unionism than in other workers' groups, with the possible exception of coal mining.

The continued and concurrent existence of the two tendencies was fully confirmed after the Bolshevik Revolution when, during the 1920s, one could witness at the same time the very strong commitment of moderate British and European union leaders such as Havelock Wilson to the reformist International Labour Office ${ }^{74}$ which during the inter-war period was to devote much special attention to maritime affairs, ${ }^{75}$ and the radicalisation of both the Australian Waterside Workers Federation and the Seamen's Union of Australia under the communist Tom Walsh. As the example of the United States demonstrated, it could be relatively small local differences which determined whether the dilemma: militancy or pragmatism,

74 It may be stressed that Wilson's strong leadership of the National Sailors' and Firemen's Union after the Great War, expectedly, resulted in the rise of a breakaway union, the Amalgamated Maritime Worker Union which, after a bitter struggle with both the shipowners (two major strikes in 1923 and 1925) and the N.U.S., was finally wiped out in 1927. See Mogridge, "Inter-Union Rivalries in British Shipping", pp. 397-406. The A.M.W.U. had in Australia and South Africa been supported by the then radical maritime unions and also took part in the General Strike of 1926.

${ }_{75}$ International Labour Office, "Seven Maritime Sessions of the International Labour Conference", International Labour Review, 78 (1958), pp. 429-460. It may well be stressed here, again, that Wilson's National Union of Seamen was the only major union not to join Britain's General Strike in 1926! 
was solved one way or another. While west-coast ports such as San Fransisco and Seattle for many years after the Great War remained influenced by syndicalist ideas, New York by contrast came in the grip of a conservative and highly corrupt longshoremen's union. ${ }^{76}$ But overall, one of the main characteristics of maritime labour in the inter-war period and even later has remained not just its remarkable rank-and-file militancy but also the widespread incidence of radical, often communist, leadership. As Miller has noted, in "countries as disparate as the United States, South Africa and Pakistan" waterside labour historically has played a significant 'avantgarde role" "."7

Fourth, and immediately following from the previous, is the point preserved in the Melbourne tradition that "[c]lass war was seen at its most ferocious on the waterfront $[\ldots]$ ". ${ }^{78}$ This expression may represent as much the attainment of a certain stage of political awareness as a perception of the fact of chronic industrial confrontation. But whatever the deeper nature of the well-documented political radicalism of maritime labour, it certainly suggests that maritime workers often believed that they, more than any other occupational group, stood at the cutting edge of the confrontation between bosses and workers. This belief cannot but have contributed to sustaining their militancy and inclination to strike. Moreover, despite their late arrival on the industrial scene and the relative isolation of maritime labour from the main bulk of the industrial workforce ${ }^{79}$ its massive strikes did have important repercussions for the general development of the labour movements in their various countries. Significantly, in view of the demonstrated ambivalence inherent in the particular conditions of maritime labour, the influences which rippled through from the waterfront could vary as much as the policies of the maritime union leaders themselves. Thus, while the victory of the London dock workers in 1889 gave a tremendous push to trade unionism in Britain and elsewhere, and in particular led to the

${ }^{76}$ Cf. Nelson, Workers on the Waterfront, and Howard Kimeldorf, Reds or Rackets: The Making of Radical and Conservative Unions on the Waterfront (Berkeley, 1989).

$n$ Miller, "Dockworker Subculture", p. 309. See also Nelson, Workers on the Waterfront, and Donald Willett, "The 1939 Tanker Strike", International Journal of Maritime History, 2 (1990), 1, pp. 155-173, for a conflict which led to a resounding defeat for such radical forces within American maritime unionism. The pragmatic leader of the National Maritime Union, Joe Curran, "was in advance of the rest of the American labour movement in purging communists from its ranks" (ibid., p. 173).

${ }^{78}$ Lowenstein and Hills, Under the Hook, p. 6. Another aspect of the same tradition is that, in Western Australia, the annual May Day parade is not held in Perth, the seat of the Trades and Labour Council but in its port-city, Fremantle.

${ }_{x}$ Due to several factors which it would carry too far to discuss here; amongst the most important of these must be regarded the historical lateness of maritime unionisation, the largely unskilled nature of maritime workers, and the relative physical isolation of maritime precincts and regions. 
rapid growth of "new unions" of largely unskilled labourers, the defeat of their colleagues in Australia and New Zealand led to totally different developments. There, trade unionism became only a force again after the labour movement had redirected itself to parliamentarian and arbitration strategies. In France, by contrast, the defeat of the Loire maritime workers led to their espousing syndicalist ideologies which, in turn, helped determine the overall policy of the syndicalist C.G.T. The defeats of German maritime workers, and also the Italian dockers, made their unions, as was the case in Britain and France after 1907, strong supporters of reformist rather than revolutionary policies. In particular the docker's union of Hamburg, by contrast to the militant workers in the city's shipyards and repair yards, tamely swelled the ranks of the bureaucratic and thoroughly accommodationist transport workers organisation.

Fifth, even if the impulses which maritime workers injected into the historical development of the labour movement of their countries were extremely significant, the men and their unions nevertheless remained largely on the periphery. Unlike, for example, coal miners, machine operators, textile workers and members of many other skilled trades they played no leading role in national union organisations and had little if any impact on the formulation and implementation of the medium- or long-term policies and strategies of those bodies. Maritime leaders generally became more interested in the pragmatic strengthening of their unions by forming alliances with other groups in adjacent occupations. Partly this happened out of strategic calculation, but partly also as extension of the natural affinity which existed between port workers and seamen. As the British example demonstrated, on this point industrial moderates and ideological militants agreed. In some countries, in consequence, alliances with coal miners and railway workers could be forged.

More importantly, maritime unions, partly resulting from a certain internationalist outlook of their members and partly because of the international competitive context of world shipping and many of the world's ports, were instrumental in establishing the first truly international trade union (as opposed to a loose confederation of national trade unions) in the International Transport Workers Federation. With a membership drawn from a large number of European nations (only after 1945 did its geographical span expand significantly) and covering large segments of both maritime and railway labour, the I.T.F. was and still is one of the very few bodies of this kind. The reformist tendency of maritime labour, however, could not have been more markedly expressed than in the support of several union leaders, like Havelock Wilson, for the International Labour Office - the fundamental basis of which was the recognition of unions by the employers' organisations. The I.L.O. would, no doubt, also have been founded without the support from this particular corner. But the very fact 
that in the inter-war period maritime labour was discussed at a good number of specific Maritime Sessions of the I.L.O. demonstrates that, at least in that large international forum, great weight was being attached to the improvement of seamen's conditions. Moreover, as the proceedings of these sessions demonstrated, in that arena pragmatic union leaders, like Wilson, could be as determined to fight for the rights and interests of their members as any radicals might have done. The root causes of the differences between pragmatists and radicals lay not just in their ideological beliefs but also in their assessment of the industrial environment in which they worked: the pragmatists were only too well aware of the overwhelming power of their opponents and, in shaping their beliefs and policies accordingly, fought only for what they thought was realistically achievable. 